\title{
食品中のグリチルリチン酸の分析法
}

(昭和 63 年 2 月 6 日受理)

$\begin{array}{lll}\text { 藤 沼 賢司* } & \text { 斉藤 和夫* } & \text { 中里光 男* } \\ \text { 菊地洋子* } & \text { 井部明広* } & \text { 二島太一郎* }\end{array}$

\section{Determination of Glycyrrhizic Acid in Foods}

\author{
Kenji Fujinuma, Kazuo Saito, Mitsuo Nakazato, Yoko Kikuchi, \\ Akihiro IBE and Taichiro Nishima \\ (The Tokyo Metropolitan Research Laboratory of Public Health: 3-24-1, \\ Hyakunincho, Shinjuku-ku, Tokyo, Japan)
}

\begin{abstract}
An analytical procedure for glycyrrhizic acid (GA) in foods by liquid-liquid extraction is presented. GA in a sample was extracted with $1 \%$ ammonium hydroxide solution. After the sample extract was adjusted $\mathrm{pH}$ to 2.0 with $3 \mathrm{~N}$ hydrochloric acid, GA was extracted with 1butanol-ethyl acetate $(3: 7)$ solvent mixture. GA in the organic layer was re-extracted with $1 \%$ ammonium hydroxide solution and the solvent was removed under reduced pressure. The residue was dissolved in $60 \%(\mathrm{v} / \mathrm{v})$ methanol and GA was determined by high performance liquid chromatography.

Recoveries of GA from a variety of food samples spiked at 20 and $100 \mu \mathrm{g} / \mathrm{g}$ ranged from 86.9 to $98.7 \%$, and averaged $93.4 \%$ with a coefficient of variation of $3.1 \%$. The detection limit of $\mathrm{GA}$ was $1 \mu \mathrm{g} / \mathrm{g}$.

In a survey of commercial foods, GA was detected at levels from 2 to $224 \mu \mathrm{g} / \mathrm{g}$ in 16 out of 56 samples.
\end{abstract}

(Received February 6, 1988)

Key words: グリチルリチン酸 glycyrrhizic acid; 液 - 液分配抽出法 liquid-liquid extraction; 高 速液体クロマトグラフィー high performance liquid chromatography

\section{緒言}

我が国において，グリチルリチン酸 (GA)のナトリウ 么塩は, 人工甘味料として,しょう油及びみそへの使用が 認められているが, GA は甘草の成分であることから, 天 然添加物として多種類の食品に広く使用されている1!.

食品中の GA の分析法は, すでに，ガスクロマトグラ フ 法 ${ }^{1) 33}$, 高速液体クロマトグラフ法 $(\text { HPLC })^{4) ~ 9) ~ な と ゙ か ゙ ~}$ 報告されているが, 一般に, 前処理法としてポリアミドカ ラムによるクリーンアップ法 ${ }^{1 \sim 6)}$ が用いられ， カラムの 目づまり防止のため透析操作を必要とする ${ }^{5)}$ (6)など，前 処理に長時間を要する. 最近, 松永らは要カートリッジカ ラムを用いたイオン対モードによる簡便な前処理法につ いて報告しているが，適用した食品の分析例は少ない。 そこで，著者らは，迅速で簡便な，しかも，多種類の

\footnotetext{
* 東京都立衛生研究所：東京都新宿区百人町 3-24-1
}

食品に適用可能な前処理法として液一液分配抽出法につ いて検討し，HPLCに適用したところ，妨害物による影 響のない高感度な分析法を確立したので報告する。

\section{実験方法}

\section{1. 試料}

しょう油： 2 検体，めんつゆ，天つゆ：各 1 検体，た れ： 4 検体, みそ: 10 検体, 漬物：10 検体, ソース：6 検体, 清涼飲料水： 2 検体，魚介乾製品： 3 検体，魚肉秝 り製品： 3 検体，あん：2 検体，チューインガム： 2 検体, チョコレート：3検体, プリン：1検体, アイスクリー ム: 2 検体, サラダ: 4 検体の合計 56 検体. いずれも市 販品を試験に供した。

\section{2. 試薬}

1）グリチルリチン酸標準原液：グリチルリチン酸標 準品 (生薬分析用, 和光純薬工業(株)) $10 \mathrm{mg}$ を精秤し, $60 \%(\mathrm{v} / \mathrm{v})$ メタノールに溶解し全量を $50 \mathrm{ml}$ とした。 


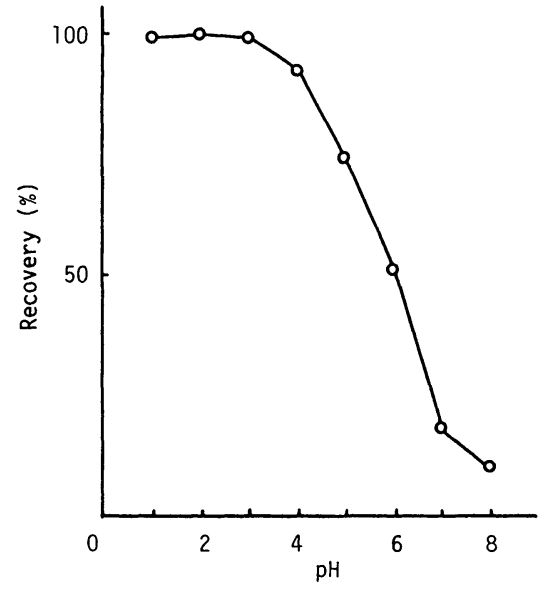

Fig. 1. Effect of $\mathrm{pH}$ on extraction of glycyrrhizic acid

Glycyrrhizic acid was distributed between water adjusted $\mathrm{pH}$ and 1-butanol, and then glycyrrhizic acid in 1-butanol was determined by high performance liquid chromatography.

2) $1 \%$ アンモ二ア水: アンモ二ア水（25２8\%，精 密分析用, 和光純薬工業(株)） $20 \mathrm{ml}$ に水を加え全量を $500 \mathrm{ml}$ とした。

$3) 3 N$ 塩酸: 塩酸 $(20 \%$, 精密分析用, 和光純薬工業 (株)） $100 \mathrm{ml}$ に水を加えて $200 \mathrm{ml}$ とした.

4) $0.2 M$ 塩化アンモニゥム溶液 $(\mathrm{pH} 2.0)$ : 塩化アン モニウム $26.7 \mathrm{~g}$ を約 $450 \mathrm{ml}$ の水に溶解し, 塩酸及びア ンモニア水で $\mathrm{pH}$ を 2.0 に調整した後, 水で全量を 500 $\mathrm{ml}$ とし $\mathrm{pH} 2.0$ の $1 M$ 塩化アンモニウム溶液を調製し た.これを用時 5 倍に希釈し, 再び, 塩酸及びアンモ二 ア水で $\mathrm{pH}$ を 2.0 に調整した後使用した。

その他の試薬は市販特級品を用いた。

\section{3. 装置}

1) ホモジナイザー: Janke \& Kunkel KG 社製ウル トラタラックス TP18-10 型及び（株）日本精機製作所製 エースホモジナイザー AM-7 型

2 ）遠心分離機：(株)久保田製作所製 KN-45 型

3 ）共栓沈殿管：(株)前田製作所製, 内容量 $250 \mathrm{ml}$

4) 高速液体クロマトグラフ：日本分光工業(株)製 BIP-1 型ポンプ, 同 UVIDEC-100-VI 型検出器, (株)島 津製作所製 C-R3A 型データ処理装置及びレオダイン社 製 7125 型インジェクターにより構成した。

\section{4. 試料溶液の調製}

1）しょう油, 清凉飲料水などの液状食品は, 試料 5 $\mathrm{g}$ に $1 \%$ アンモニア水 $45 \mathrm{ml}$ を加えて試料溶液とした.

2) みそなどの半固形食品及び清物などの固形食品 は, 試料 $15 \mathrm{~g}$ に1\%アンモニア水を加え, 全量を 150 $\mathrm{ml}$ とした後, ウルトラタラックスでホモジナイズした. 心要に応じて遠心分離した後乃過し，万液 $50 \mathrm{ml}$ を試料 溶液とした。

3 ）アイスクリーム，チョコレートなどの乳製品及び チューインガムは, 試料 $10 \mathrm{~g}$ にジクロロメタン $40 \mathrm{ml}$ 及び $1 \%$ アンモニア水 $50 \mathrm{ml}$ を加えホモジナイズし, 遠 心分離した後水層を分取した，さらに，ジクロロメタン 首に $1 \%$ アンモ二ア水 $40 \mathrm{ml}$ を加え共栓沈殿管中で振と うし，遠心分離した後水層を分取した。水層を合わせ， 水で全量を $100 \mathrm{ml}$ とした後ろ過し，ろ液 $50 \mathrm{ml}$ を試料 溶液とした。

\section{5。試験溶液の調製}

得られた試料溶液を $3 N$ 塩酸で $\mathrm{pH} 2.0$ に調整した後, 1-ブタノールー酢酸エチル $(3: 7)$ 混液 $50 \mathrm{ml}$ で 2 回抽出 した，層の相互分離が不十分な場合には，必要に応じて 遠心分離を行い有機層を分取した．有機層はろ紙でろ過 した後, $0.2 M$ 塩化アンモニゥム溶液 $(\mathrm{pH} \mathrm{2.0)} 30 \mathrm{ml}$ で 1 回洗浄し, 次に, $1 \%$ アンモ二ア水 $30 \mathrm{ml}$ で 2 回 GA を抽出した.

抽出液にエ夕ノール約 $20 \mathrm{ml}$ を加え, 減圧下, 約 $40^{\circ}$ で濃縮した後, $60 \%(\mathrm{v} / \mathrm{v}) \times$ タノールで全量を $5 \mathrm{ml}$ と し, 試験溶液とした。

\section{HPLC 条件}

試験溶液を下記の条件下, HPLC に付し, 定性及び定 量を行った。

カラム: Hibar Column LiChrosorb RP-18 $(10 \mu \mathrm{m}$, $250 \times 4$ mm i.d.)

移動相：メタノール $-2 \%(\mathrm{v} / \mathrm{v})$ 酢酸 $(500: 300)$

流速: $1.5 \mathrm{ml} / \mathrm{min}$

測定波長： $254 \mathrm{~nm}$

注入量: $50 \mu 1$

\section{7. 検量線の作成}

$\mathrm{GA}$ 標準原液を $60 \%(\mathrm{v} / \mathrm{v})$ ×タノールで希釈し，5〜 $50 \mu \mathrm{g} / \mathrm{ml}$ の標準溶液を調製した。 その $50 \mu \mathrm{l}$ を HPLC に付し，ピーク面積法により検量線を作成した。

\section{結果及び考察}

GA はグリチルレチン酸及び 2 分子のグルクロン酸か らなるトリカルボン酸であることから, 酸性条件下での 極性の大きい有機溶媒による直接抽出条件について検討 を行った。

\section{1. 抽出条件の検討}

1) $\mathrm{pH}$

塩酸あるいはアンモニア水で $\mathrm{pH}$ を 1 8 に調整した $\mathrm{GA} 100 \mu \mathrm{g} / \mathrm{ml}$ を含有する $1 M$ 塩化アンモニウム溶液 $100 \mathrm{ml}$ に対して, 抽出溶媒として1-ブタノール $50 \mathrm{ml}$ を用いて 20 分間振とうし，1-ブタノール中の $\mathrm{GA}$ 量を 測定した。 その結果, Fig. 1 に示したように, 抽出率は, $\mathrm{pH}$ 1〜3 の範囲で約 99\%と一定の值を示し, pH 4 以上 では $\mathrm{pH}$ の増大とともに減少した。 そこで, 抽出時の試 
料溶液の $\mathrm{pH}$ は 2.0 に設定した。

2 ) 抽出溶媒

pH 2.0 において，種々の溶媒による GA の抽出率に ついて検討を行った. 水層 $100 \mathrm{ml}$ に対して, それぞれ, 抽出溶媒 $50 \mathrm{ml}$ を用いて 1 回抽出を行ったときの抽出 率を Table 1 に示した. 1-ブタノール 99\%, 酢酸エチル 93\%，4-メチル-2-ペンタノン 90\%，エチルエーテル $34 \%$ であり，1-ブタノール，酢酸エチルが高い抽出率を 示した. しかし，1-ブタノールのみでは極性が大きく， 試料から多くの夾雑物が抽出されるため，1-ブタノール と酢酸エチルとの混合溶媒について検討を行った。 その 結果, 溶媒比が 3 対 7 では $98 \%$ の抽出率を示し, また, $1 \%$ $\%$ アアア水で $\mathrm{GA}$ を再度抽出する際の層の相互分 離は良好であった。 また，比較的抽出率の良かった 4-メ チル-2-ペンタノンと1-ブタノールとの混合溶媒につい ても検討を行ったが，1\%アンモニア水で再抽出する際 の層の相互分離は悪く，良い結果は得られなかった。

なお，抽出溶媒として用いた酢酸エチルは $1 \%$ アンモ 二ア水で再抽出する際，その一部が加水分解され，試験 溶液中に約 $8 \%$ 程度の酢酸アンモニウムの生成が認めら れた，そこで，HPLCにおける GA の定量值及び保持時 間に及ぼす酢酸アンモニウム濃度の影響について検討を 行った。その結果は Table 2 に示したように, 酢酸アン モニウム濃度が増大すると保持時間がわずかに早くなる 傾向が認められたが，定量値への影響はほとんど認めら れなかった。

Table 1. Effect of Solvents on Extraction of Glycyrrhizic Acid

\begin{tabular}{lc}
\hline \multicolumn{1}{c}{ Solvent } & Recovery $(\%)$ \\
\hline 1-Butanol & 99 \\
1-Butanol-ethyl acetate $(5: 5)$ & 98 \\
1-Butanol-ethyl acetate $(3: 7)$ & 98 \\
1-Butanol-ethyl acetate $(1: 9)$ & 97 \\
Ethyl acetate & 93 \\
4-Methyl-2-pentanone & 90 \\
Ethyl ether & 34 \\
\hline
\end{tabular}

以上の結果から, 抽出溶媒としては, 抽出率が良く, 層の相互分離も良好であった 1-ブタノールー酢酸エチ ル $(3: 7)$ 混液を用いることとした。

\section{2. 検量線の作成}

検量線は 5〜 50 $\mu \mathrm{g} / \mathrm{ml}$ の範囲で直線性が得られた。 また，本法における GA の定量限界は, 試料中濃度とし

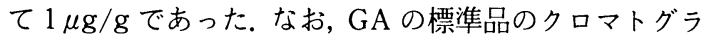
ムを Fig. 2 に示した。

\section{3. 添加回収実験}

あらかじめ GA が検出されないことを確認した試料 について添加回収実験を行った. GA を 20 及び $100 \mu \mathrm{g} /$ g になるように添加し，本法に従って操作したときの 回収率を Table 3 に示した。魚肉ねり製品で約 $87 \%$ の 回収率を示した他は，いずれも $90 \%$ 以上であった。な お, $20 \mu \mathrm{g} / \mathrm{g}$ 添加における平均回収率は $93.5 \%$, 変動係 数 $3.2 \%$ ，また， $100 \mu \mathrm{g} / \mathrm{g}$ 添加における平均回収率は 93.4\%，変動係数 3.1\%で，添加量による回収率に差は なく，食品の種類による回収率の差もほとんどないこと がわかった。

なお，試料のクロマトグラムの一例を，Fig. 3 に示し た、GAのリテンションタイム付近に妨害となるピーク

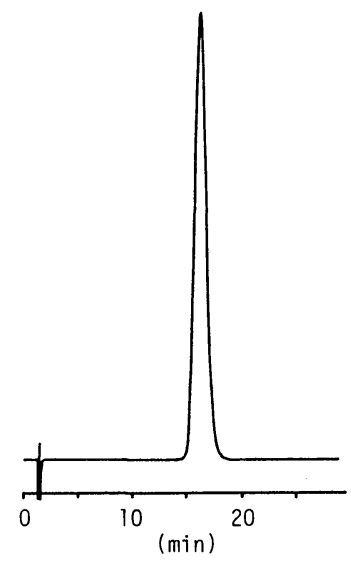

Fig. 2. High performance liquid chromatogram of glycyrrhizic acid

Table 2. Effect of Ammonium Acetate Concentration on Analytical Value and Retention Time of Glycyrrhizic Acid in High Performance Liquid Chromatography

\begin{tabular}{ccc}
\hline \hline Ammonium acetate $(\mathrm{w} / \mathrm{v} \%)$ & Analytical value $(\mu \mathrm{g} / \mathrm{g})$ & Retention time $(\mathrm{min})$ \\
\hline 0 & $49.7,50.1$ & $15.9,15.8$ \\
5 & $49.8,50.0$ & $15.7,15.6$ \\
10 & $50.2,50.4$ & $15.7,15.5$ \\
20 & $50.1,49.6$ & $15.6,15.2$ \\
30 & $50.5,49.7$ & $15.5,15.2$ \\
Av. & 50.0 & 15.6 \\
\hline
\end{tabular}


Table 3. Recovery of Glycyrrhizic Acid Added to Foods

\begin{tabular}{lcc}
\hline \multirow{2}{*}{ Sample } & \multicolumn{2}{c}{ Recovery (\%) } \\
\cline { 2 - 3 } & $20 \mu \mathrm{g} / \mathrm{g}$ & $100 \mu \mathrm{g} / \mathrm{g}$ \\
\hline Soy sauce & 96.1 & 94.4 \\
Miso & 93.2 & 90.7 \\
Pickles (Takuan-zuke) & 98.7 & 97.0 \\
Sauce & 92.6 & 96.0 \\
Soft drink (Canned coffee) & 93.3 & 92.3 \\
Dried fish and shellfish (Smoked octopus) & 93.5 & 90.2 \\
Fish paste product (Kamaboko) & 86.9 & 87.3 \\
Bean jam (An) & 90.9 & 93.9 \\
Chewing gum & 95.3 & 97.2 \\
Chocolate & 91.5 & 92.7 \\
Custard pudding & 96.1 & 94.9 \\
Ice cream & 94.1 & 93.6 \\
& & \\
Av. & 93.5 & 93.4 \\
S.D. & 3.0 & 2.9 \\
CV (\%) & 3.2 & 3.1 \\
\hline
\end{tabular}
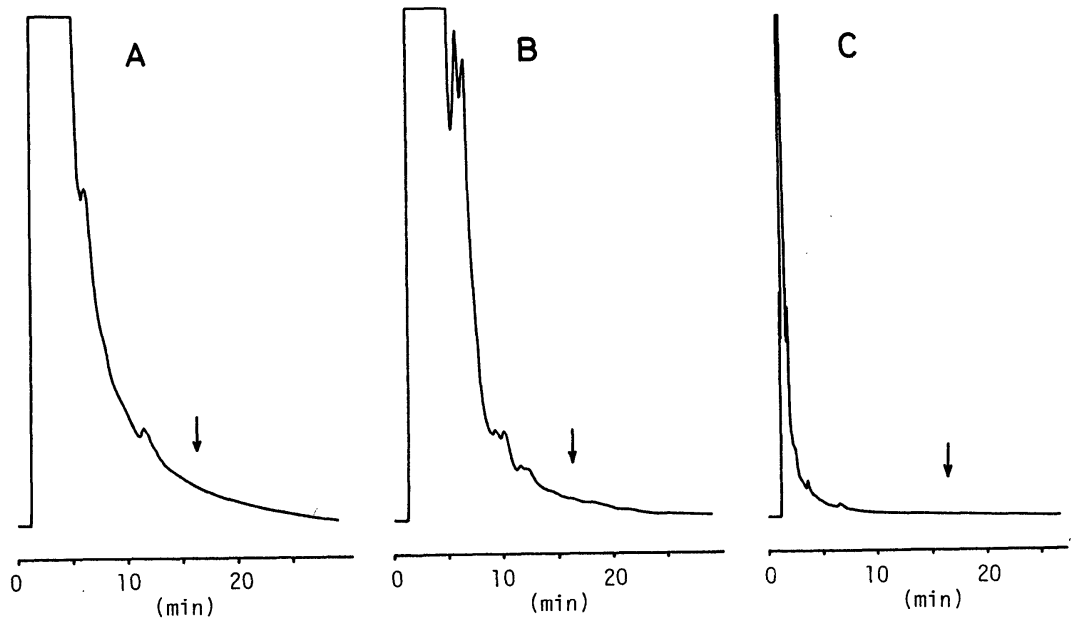

Fig. 3. High performance liquid chromatograms of sample extracts A: soy sauce; B: miso; C: chewing gum

は認められなかった。

\section{4. 市販食品の調査}

本法を用いて, 市販食品 56 検体について調査を行った 結果を Table 4 に示した. 漬物では 52〜224 $\mu \mathrm{g} / \mathrm{g}$, 魚 介乾製品では 110 及び $135 \mu \mathrm{g} / \mathrm{g}$ の $\mathrm{GA}$ が検出され，こ れらの場合, 甘味の目的で使用されているすのと思われ る. また, めんつゆ, 天つゆ, たれ, ソース, サラダでは $2 \sim 21 \mu \mathrm{g} / \mathrm{g}$ と検出量は少なく, これらの場合, 原料由来 によるものか, あるいは, 砂糖が併用されていることか ら甘味の調整剤として使用されているあのと思われる.

なお，GA の検出された試料のクロマトグラムの一例
をFig. 4 に示した. GA のピークの他に, リテンション タイム 11 分及び 19 分付近に甘草由来と思われるピー クが検出されたが, GA との分離は良好であった。

\section{要約}

液一液分配抽出法による食品中の GA の前処理法に ついて検討した。

1) 抽出溶媒として用いた1-ブタノールー酢酸エチ ル $(3: 7)$ 混液は抽出率が高く, 層の相互分離は良好であ った.

2 ）試料に 20 及び $100 \mu \mathrm{g} / \mathrm{g}$ になるように GA を添 加した場合の回収率は，魚肉ねり製品で約 $87 \%$ の值を 
Table 4. Contents of Glycyrrhizic Acid in Commercial Foods

\begin{tabular}{|c|c|c|c|c|c|c|c|c|}
\hline \multirow{2}{*}{$\begin{array}{l}\text { Sample } \\
\text { Soy sauce }\end{array}$} & \multicolumn{8}{|c|}{ Glycyrrhizic acid $(\mu \mathrm{g} / \mathrm{g})$} \\
\hline \multirow{2}{*}{\multicolumn{9}{|c|}{ Soy sauce products }} \\
\hline & & & & & & & & \\
\hline Mentsuyu & 10 & & & & & & & \\
\hline Tentsuyu & 21 & & & & & & & \\
\hline Tare & $\mathrm{ND}$ & ND, & 6 & 12 & & & & \\
\hline Miso & $\begin{array}{l}\text { ND, } \\
\text { ND, }\end{array}$ & $\begin{array}{l}\text { ND, } \\
\text { ND }\end{array}$ & ND, & $\mathrm{ND}$ & ND, & ND, & ND, & ND \\
\hline \multicolumn{9}{|l|}{ Pickles } \\
\hline $\begin{array}{l}\text { Takuan-zuke } \\
\text { Soaked in vinegar }\end{array}$ & $\begin{array}{l}\mathrm{ND} \\
\mathrm{ND}\end{array}$ & $\begin{array}{l}\text { ND, } \\
\text { ND }\end{array}$ & 52 & 81, & 101, & 110 & 132 , & 224 \\
\hline Sauce & ND, & ND, & ND, & ND, & 3 & 8 & & \\
\hline Soft drink (Canned coffee) & ND, & ND & & & & & & \\
\hline \multicolumn{9}{|l|}{ Dried fish and shellfish } \\
\hline Saki-ika & 110 & & & & & & & \\
\hline Smoked squid & 135 & & & & & & & \\
\hline Smoked octopus & ND & & & & & & & \\
\hline Fish paste product (Kamaboko) & ND, & ND, & ND & & & & & \\
\hline Bean jam (An) & ND, & ND & & & & & & \\
\hline Chewing gum & ND, & ND & & & & & & \\
\hline Chocolate & ND, & ND, & ND & & & & & \\
\hline Custard pudding & ND & & & & & & & \\
\hline Ice cream & ND, & ND & & & & & & \\
\hline Salad (Macaroni salad) & $\mathrm{ND}$, & ND, & 2 & 2 & & & & \\
\hline
\end{tabular}

ND: not detectable
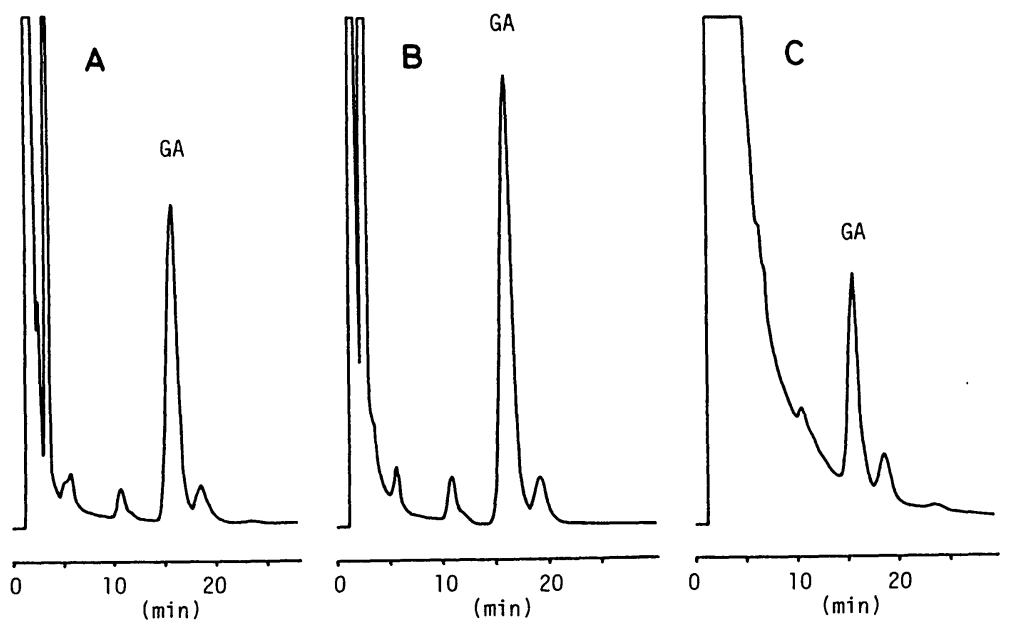

Fig. 4. High performance liquid chromatograms of sample extracts

A: pickles (takuan-zuke); B: dried cuttlefish product (saki-ika); C: soy sauce product (mentsuyu); GA: glycyrrhizic acid

示した他はいずれも $90 \%$ 以上であった。

3）本法を 56 検体の市販食品に適用したところ，16 検体から 2 224 $\mu \mathrm{g} / \mathrm{g}$ の GA が検出された.

4) 本法は多種類の食品に適用可能であり, また, 定 量限界は試料中濃度として $1 \mu \mathrm{g} / \mathrm{g}$ であった。
文献

1）厚生省環境衛生局食品化学課：“食品添加物の 1 日摄取量 調查に関する研究” p. 15 18 (1983).

2）日本薬学会編：“衛生試験法・注解” p. 333 336 (1980), 金原出版. 
3）厚生省環境衛生局食品化学課編：“食品中の食品添加物分 析法” p. 589 593 (1982), 講談社.

4）加藤三郎：衛生化学 26, 318～321 (1980).

5）山田利治, 中岡正吉, 池田陽男: 神奈川県衛研所報. No. $10,5 \sim 8(1980)$.

6）北田善三, 玉瀬喜久雄, 佐々木美智子, 西川喜孝: 食衛誌. 21, 354 359 (1980).
7）厚生省生活衛生局食品化学課：“食品中の天然食品添加物 分析法試案” p. 139 143 (1985).

8）今井田雅示, 吉田綾子, 尾花裕孝: 大阪府立公衛研所報. 食品衛生編 No. 16, 57〜61 (1985).

9）松永明信, 大戸幹也, 山本 敦, 斎藤行雄, 牧野正雄: 食 衛誌. 27, 408 412 (1986). 